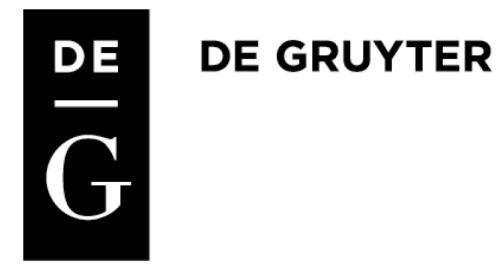

Stanisław Jankowiak (Adam Mickiewicz University, Poznań)

\title{
THE “GRYFICE SCANDAL" IN POZNAŃ - DEALING WITH ABUSES COMMITTED IN THE PROCESS OF ESTABLISHING COOPERATIVE FARMS IN THE POZNAŃ REGION
}

Several years after the war, a revolution started in the Polish agriculture - even though until 1948, the authorities claimed that farms in Poland would not be collectivized. The new stage meant that things accelerated quickly. Central party authorities determined the number of cooperatives to be established per year in a top-down manner. The Poznan region was considered particularly opposed to the system, hence the pressure to establish cooperative farms was particularly intense. The quick pace of the operation and accountability of the party officials for its results meant that they often resorted to prohibited methods of forcing resistant individuals to enter into cooperatives. Though party guidelines emphasized that the process was voluntary, and formally banned any form of pressure, various forms of power abuse were tolerated in practice. Only when the situation rapidly escalated into scandals, the authorities stigmatized the illegal methods. However, after a while, the situation returned to normal, and the anomalies reoccurred. The problem was that the principles of the operation were flawed. One of the party activists claimed that establishing cooperatives according to the guidelines would have taken 200 years to complete. Farmers had to be coerced, otherwise they would never have joined cooperatives. Most cooperative farms established this way collapsed in 1956.

Key words: cooperative farms, kolkhozes, repressions in the countryside, Stalinism

doi:10.1515/sho-2017-0005

\section{INTRODUCTION}

Right after the war, the authorities promoted a policy of equal treatment of all sectors in the countryside, and tried to persuade farmers that individual agricultural holdings were to be an everlasting element of the rural reality. However, the defeat of the political opposition in the 1947 election, combined with the changes in international politics, allowed the authorities to launch more offensive actions. As early as April 1947, the di- 
vision of the economy into three sectors came under heavy attack on the part of the political leaders of the time ${ }^{1}$. Final decisions concerning the direction of changes affecting rural areas in socialist states were made during the Information Bureau conference in Bucharest in June 1948. This is when the systemic reformation of the countryside was identified as the main objective. Small and medium holdings were meant to be combined into cooperative farms and large holdings (belonging to affluent "kulaks") were meant to disappear. These guidelines evolved into an ideological declaration of the Polish United Worker's Party (PUWP), which emphasized that providing prosperity to farmers was only possible through collective economy in the form of cooperative farms ${ }^{2}$. The transition to the construction of the "foundations of socialism" had to involve a radical change in the policy towards the Polish countryside. A fundamental objective was the establishment of cooperatives and the simultaneous elimination of "kulaks". This was meant to lead to major changes in the property profile in the countryside. This is when "major efforts were made to make the working class aware of their leading role on the path to the socialist reconstruction of the countryside, to make the masses of poor and medium farmers more active, and liberate them from the hostile influence of the class of rural capitalists" 3 .

Party committees at all levels were burdened with the task of establishing cooperatives. The problem was often discussed during the meetings of regional authorities, and was by no means simple. It must be noted that various unfavorable circumstances overlapped in the process. The basic issue was the pace of the transformation. Additionally, the people involved in the process had no prior experience, and only completed short trainings which could not compensate for these shortcomings. Finally, central authorities held the regional committees accountable for the number of established cooperatives. The combination of all these factors meant that the process of collectivization could not go without aberrations. Difficulties

${ }^{1}$ Shorthand report of the plenary session of the PUWP Central Committee, April 13-14, 1947 [in] Archiwum Ruchu Robotniczego [Archive of the Workers' Movement], vol. 7, Warsaw, 1982, p. 290

2 Ideological declaration of the PUWP, "Nowe Drogi" [New ways], 1949, no. 1, p. 16

3 "On the current tasks of the Party in the countryside". From the resolution of the Organizational Bureau of the PUWP Central Committee, May 1949, [in] O budownictwie partyjnym. Uchwaty Komitetu Centralnego Polskiej Zjednoczonej Partii Robotniczej 1949-1953 [On the Party construction industry. Resolutions of the Polish United Worker's Party Central Committee 1949-1953], Warsaw, 1954, p. 141. 
piled up particularly in Greater Poland. The authorities had poor grasp of the mentality of farmers in Greater Poland, who had focused for ages on protecting their property. The authorities assumed that resistance towards cooperatives was a sign of poor political awareness of farmers in the Poznan region.

The Poznań countryside is conservative, influenced by reactionary movements, easily affected by word-of-mouth propaganda spread by kulaks and clergy. [...] The greatest difficulties in any kind of activity, and specifically in the development of cooperative farms, lay in the absence of class struggle in the countryside and in the solidarity between small and medium farmers with kulaks and affluent farmers ${ }^{4}$.

In these conditions, declarations concerning the voluntary nature of cooperatives did not sound convincing. Furthermore, in the system, decisions concerning the number of cooperatives to be established in Greater Poland were made at the central level, while the Regional Committee was only responsible for implementing the task. Of course, the responsible officials delegated the tasks to still lower ranking activists, who made as little effort as possible. As early as 1948, eighty villages were selected where cooperatives were to be established. The selection was made "in the office" rather than "in the field", and therefore the results were foreseeably poor. According to the report: "The County Committee selected the villages, but nobody wants to join the cooperatives". It was also added that the selected villages were perfect for establishing cooperatives, the only problem being that farmers did not want to comply ${ }^{5}$. A solution was quickly found - the Citizens' Militia, Security Office and courts became involved. The attitude of field activists to the "freedom" of collectivization was best expressed by an activist from Rawicz who said that:

he knew the resolution of the Political Bureau, but did not agree, because if he were to establish cooperatives according to the resolution, "it would take 300 years or more to build socialism in the countryside. I have been working here for 16 years and I know farmers well [...] and if you do not force them, there will be no cooperatives. I summoned farmers for 10 days, every day from dusk till dawn, and we have results some of them signed the statute of the cooperative farm" ${ }^{\prime \prime}$.

\footnotetext{
${ }^{4}$ National Archive in Poznań, Domestic Affairs Office, sign. 77, Situational report for the $2^{\text {nd }}$ quarter of 1950 .

5 The Archive of New Files in Warsaw, PUWP Central Committee, sign. 237/VII1792, Report of the PUWP Regional Committee in Poznan for the period from March 15 to April 15, 1949.

${ }^{6}$ National Archive in Poznań, PUWP Regional Committee, sign. 264, Minutes of the meeting of the PUWP Regional Committee Executive Body on January 31, 1951, see:
} 
From the very beginning of the process, the Central Committee (followed by the Regional Committees) suffered from a peculiar form of megalomania. First "successes" led to plans for intensifying efforts in this area. From March until the end of 1949, 32 cooperatives were established in the Poznan region, and by the end of 1950 - another 251. This made regional authorities hungry for more. During a plenary session of the Regional Committee, it was optimistically assumed that:

nowadays in our region there is no village and no house where cooperative farms would not be discussed and debated. There is no village where the masses of poor and medium farmers would not struggle with kulaks and those small and medium farmers who, intoxicated by the kulaks' reactionary propaganda, do not understand the economic and political significance of cooperative farms ${ }^{7}$.

In December 1951, a plan was adopted to create 255 new cooperatives in the period from December 15, 1950 until April 1, 1951, so that the total number would exceed 500 in April 1951. Only one of the activists was critical of this optimistic plan. He emphasized that establishing cooperatives was a matter of political and organizational planning, rather than just setting target figures. When planning the development of cooperatives, County Committees should avoid mechanical planning and chasing after figures. "[...] cooperatives should be established from the bottom up, as a result of the effort of the village, as a result of class struggle against kulaks" ${ }^{\prime}$. He suggested a review of the plan, which was approved by the executive body of the Regional Committee. This was significant, as until June 1, 1950, only 73 cooperative farms were established in the Poznan region, so the actual pace was in sharp contrast with the ambitious plans. "Activation" in the second half of the year produced the desired effect, as in this period, 154 cooperatives were established, and it happened a month ahead of the plan. On December 1, 1950 there were 227 cooperatives in the region. Interestingly, only 22 were type 1 , even though this was the simplest form. 109 were type 2, and 96 - type $3^{9}$. By December 15 , the number of cooperatives grew to 254 .

Jankowiak S. (1995), Wielkopolska w okresie socjalizmu 1948-1956 [Greater Poland in the period of socialism 1948-1956], Poznań, p. 103-104.

${ }^{7}$ National Archive in Poznań, PUWP Regional Committee, sign. 46, minutes of the PUWP Regional Committee plenary session of January 11, 1951.

${ }^{8}$ National Archive in Poznań, PUWP Regional Committee, sign. 263, Minutes no. 52 from the session of the PUWP Regional Committee Executive Body on December 20, 1950.

${ }^{9}$ Ibidem. 
Early experiences from the period of establishing cooperative farms demonstrated that the rules, in combination with a massive pressure on the part of central authorities to implement the process, led to the adoption of "shortcuts". One example is the issue of a cooperative farm in Krzyżowniki (Środa County), discussed during a meeting of the Regional Committee Executive Body. Party activists who came to Krzyżowniki simply announced that a cooperative had to be established there on that exact day.

When they started to pressure farmers by confiscating livestock and other possessions, farmers started signing declarations, concerned that more would be taken away and further repressions would occur ${ }^{10}$.

Even the authorities started to see a problem. In the resolution adopted in May 1949, the situation was accurately diagnosed, but the potential threats were obviously disregarded, and it was emphasized that such incidents were not too frequent.

The few deplorable attempts to threaten farmers into creating cooperative farms are an example of the worst kind of wrongdoing, and are the expression of concealed opportunism, and a fear of collective effort, which is replaced with oppression ${ }^{11}$.

It was also pointed out that overly eager local activists tried to force farmers to create the most advanced cooperatives (type 3) instead of trying to persuade them (at least in the initial period) to undergo the simplest type of reorganization into type 1 cooperatives. Conclusions from the first experiences were drawn and it was advised that in the future:

harmful pressure, superficial approach and rush resulting from the desire to achieve quantitative results should be avoided when organizing cooperative farms. The existing cooperatives should be strengthened and establishing committees should be quickly transformed into cooperative farms ${ }^{12}$.

A decision was also taken to activate party members by making county secretaries personally liable for the development of cooperatives in their county $^{13}$. However, even these recommendations were a source of future

\footnotetext{
${ }^{10}$ Ibidem.

11 Ibidem.

12 Ibidem.
}

13 On the current tasks of the Party in the countryside. From the resolution of the Organizational Bureau of the PUWP Central Committee, May 1949, [in] O budownictwie... [On the Party...], p. 143 
problems. Committees could not avoid rush, as they were burdened with creating a set number of cooperatives in a given year, and at the same time they were held accountable for the achievement of this goal.

A year later, a "summary" of the first stage of the collectivization process in the Polish countryside was prepared. Here, the belief in the creative power of the word (typical for that period) once again manifested itself. The party resolution emphasized the progress made by cooperatives, and claimed that they achieved good economic results, being $20-40 \%$ more efficient than individual holdings. This kind of wishful thinking could also be seen in the declaration that:

every year of the existence of cooperative farms practically and tangibly proves what results farmers organized in cooperatives achieve, exposes the slanders of kulaks, and causes increased interest in cooperative farms among masses of farmers ${ }^{14}$.

Pride with achievements made the authorities oblivious to threats resulting from pressuring farmers to establish cooperatives. Among the disadvantageous effects, only the following was mentioned: "distraction from current economic tasks of the countryside due to struggle to develop cooperative farms" and "inefficient reliance on the poor masses" (Lenin's rule of transforming the countryside was referred to on this occasion: rely on the poor masses in agreement with the medium-sized farmers, but never stop fighting with kulaks). Based on this rule, the authorities stigmatized a lack of vigilance demonstrated in accepting kulaks into cooperatives ${ }^{15}$. Only later was it noted that:

in the struggle for the development of cooperative farms, much harm was caused by tendencies to replace consistent massive political work when organizing cooperative farms with means of administrative pressure, revealed in some counties, mainly in the old territories. [...] in some counties, the rule of voluntary joining was broken by using administrative pressure, threats to make family members unemployed, summoning to the office of the Communal National Council, imposing fines and excessive taxation. The party organizations made a serious mistake in their efforts for the development of cooperatives by adopting a method of selecting certain villages in advance for cooperative farms [...] In the chase after quantity, weak and unpromising cooperatives were created. [...] in many cases, when establishing cooperative farms, party organizations decided to take the path of demoralizing promises. Better land was promised, and small and medium farmers who decided not to not join cooperatives were disadvantaged, as this better land was assigned to the cooperative, and kulaks' land was

14 On the tasks of the Party in the field of developing cooperative movement and increasing political, economic and organization impact of the National Machinery Centers (POM), [in] O budownictwie... [On the Party...], p. 146

15 Ibidem, p. 149. 
most frequently left out in the exchange. [...] County Committees tolerated and very often stood behind granting loans to cooperatives whose members were unwilling to go to work, which were used to pay large advance payments, sometimes exceeding the workers' daily wage ${ }^{16}$.

Such aberrations also took place in the Poznan region, for instance in Jarocin County. The problem was discussed during a meeting of the Regional Committee Executive Body on December 20, 1950. This is when the case of a County Committee activist who had committed abuses during the establishment of cooperatives in Orgin and Boguszyn was debated. The activist did not stop at threats, but also used physical violence. He pushed a woman against a wall, shook her and said: "you dumb, emptyheaded woman, I will smash this dumb head of yours against the wall behind you, what will you do with that"? He also told her husband to dig his own grave, as he was a class enemy. He also allegedly said to farmers: "you pieces of shit, you'll end up in a trash". This created such an atmosphere of fear that "when the farmers saw a car in the village, they hid in attics and haystacks"17. One member of the executive body defended the activist, saying that it was the County Committee who had told Antkowiak to organize a cooperative and he tried to implement this task at any price and did it the only way he knew how, even though he was only a worker in a State Agricultural Farm. The First Secretary of the Regional Committee, Baranowski, wanted the guilty activist to be punished, emphasizing that his behavior jeopardized the development of the cooperative movement in Jarocin County, and the punishment was to show the County Committees "what consequences must be accepted by those who use pressure for establishing cooperatives". In the end, the culprit was dismissed from his position of the County Committee instructor in Jarocin, dismissed from work in the party, and banned from taking positions for two years. The secretaries of the County Committees were also obliged to constantly monitor the behavior of party employees towards farmers, and to ensure tactful and respectful treatment of farmers by party officials ${ }^{18}$. The problems of abuses in Greater Poland reached the Central Committee. They decided to react by sending a letter from B. Bierut to the PUWP Regional Committee in Poznań. In response, the Regional Committee humbly admitted that they

16 Ibidem, p. 150-151.

17 National Archive in Poznań, sign. 263, the Resolution of the PUWP Regional Committee Executive Body of December 20, 1950 on using pressure when establishing cooperative farms in Jarocin county.

${ }^{18}$ Ibidem. 
had underestimated the need to constantly monitor the work of activists in the field, and had not imposed severe consequences towards those using unacceptable methods of pressure towards the farmers. Only the resolution of the Central Committee helped the executive body to take the right position ${ }^{19}$. The ritual went on and neither the reality nor the methods used changed.

In practice, the most serious problem was the pace of rural cooperative development. Pressure from the central authorities to accelerate the "socialist reconstruction of the rural areas", in combination with the accountability of regional organizations for the implementation of the task, meant that "field activists" tried to speed up the process. As a result, the rule of law was broken on a large scale. The situation became so serious that central party authorities had to intervene. The party organization in Gryfice in the Szczecin region was made an example of. In a special resolution, the Central Committee stigmatized cases of "perverting the party line" in the actions towards farmers. This concerned not only the development of cooperatives, but also the implementation of the mandatory purchases. Teams composed of National Machinery Center employees and the members of the Polish Youth Association "performed acts of illegal confiscation at farmers' houses". Criminal acts of the brigade, which in seven cases involved the destruction of the farmers' property [...], had been applauded. [...] County management, which was turning into a clique, terrorized honest members of the Party. Also, the party policy towards kulaks was perverted. "In several cases, repressions were used towards kulaks without any actual causes - they were treated like criminals only because they were kulaks". It was announced, in few words, that:

the creation of 15 cooperative farms in Gryfice County in this period took place in an atmosphere that by no means ensured respect for the inviolable principle of the voluntary forming of cooperatives. [...] The Gryfice clique also used false attitudes which were slowly shaping in the Regional Committee, expressed for instance in the view that perversions in the Party's political line cannot be avoided if one wants to achieve the target for cereal purchases ${ }^{20}$.

${ }^{19}$ National Archive in Poznań, sign. 265, a letter of PUWP Regional Committee in Poznań to B. Bierut, the president of the PUWP Central Committee in Warsaw of February 14, 1951.

${ }^{20}$ Breaking the party line in the Gryfice organization in the Szczecin region [in] O budownictwie... [On the Party...], p. 235-237. 
The second case publicized by the PUWP Central Committee was the situation in Drawsko County. In the adopted resolution, the Central Committee emphasized that the County Committee management was controlled by a criminal clique and:

broke the rule of voluntariness in establishing cooperative farms on a large scale, and frequently used a system of illegal extra taxation, unjustified administrative penalties, and even illegal detention by the Security Office and Citizens' Militia officers.

It was also emphasized that the County Committee acted this way after the case in Gryfice had been condemned in May $1951^{21}$.

Official condemnation of the abuse in Gryfice meant that the process of establishing cooperative farms came under scrutiny throughout the country. In Poznań, this problem was debated during a plenary session of the PUWP Regional Committee on June 13, 1951. A speech summarizing the problem was made by the Regional Committee First Secretary, Feliks Baranowski. Regarding the situation in Gryfice, Baranowski said that in their efforts to achieve cereal purchase targets, the management of the Gryfice organization did not use methods worthy of the revolutionary party - instead of penetrating the rural masses and persuading them that our economic policy is right, they used the methods of oppression, terror and pressure to achieve results. These methods meant that "during the purchase operation in Gryfice County, saboteurs came into play, and made farmers confused and hostile towards the ruling party. In Gryfice County, farmers fell victim to criminal methods, even theft. In seven cases, farmers' property was destroyed. [...] Cooperatives created during the purchase operation in Gryfice County were established in an atmosphere of oppression and terror" ${ }^{22}$. After this introduction, he admitted that also in the Poznan region, there had been cases of abuse and breaking the party line during the purchase operations and the establishment of cooperative farms.

We see isolation from nonpartisan masses, we see violation of the rule of law, we see a number of attempts to replace serious political work with means of administrative pressure and even terror". [...] "There were some who thought that the development of cooperative farms must involve deception, that persuasion and profound politi-

${ }^{21}$ Breaking the party line by the County Committee in Drawsko [in] O budownictwie... [On the Party...], p. 242-243.

22 National Archive in Poznań, PUWP Regional Committee, sign. 48, Minutes of the plenary session of PUWP Regional Committee of June 13, 1951. 
cal work is pointless when dealing with farmers. There were some who thought that farmers must be tricked ${ }^{23}$.

As an example of breaching the party line, he mentioned the already stigmatized Jarocin County, where County Committee "activists" resorted to despicable and deplorable methods when establishing cooperative farms. [...] They tormented farmers with never-ending meetings, lasting until midnight, and in one case even, until five in the morning. They threatened local land owners that if they did not sign the declaration of joining the cooperative, their lease rent would be tripled, their cows and clothing would be confiscated, their children would be taken away from them, they would be displaced, and all the stubborn ones would be arrested. As it turned out, these were not just empty threats, as the local Citizens' Militia started to interrogate and detain some of those stubborn farmers. The activists used "vulgar invectives and even physical violence". Baranowski provided the example of a farmer whose wife did not want to enter into a cooperative. A County Committee activist grabbed her and said: "woman, you have a hard head, if I squeeze it, your eyes will pop out" 24 .

The actions of the County Committee turned out to be so effective that "farmers ran away from their houses to the fields every time they saw a car approaching, and were afraid of all strangers". In Potarzyce, Gostyn County:

small and medium farmers fell victim to appalling acts of criminality - they had their land taken away from them and given to the newly established cooperative farm. Among 18 farmers, there were two who had only one hectare each, and the land was taken away from both of them.

When farmers tried to protest, in the County National Council they were told they could write complaints if they want, but no one was going to care. As a result:

in and near Potarzyce, this violence and these criminal acts were remembered bitterly, farmers remembered the damage that had been done to them by people who called themselves the representatives of our authorities and our Party.

Similar methods were used in Wągrowiec County. This time, the perpetrator was the president of the County National Council. Similar incidents took place in other counties of the region. Sometimes, like in Trzcianka

\footnotetext{
${ }^{23}$ Ibidem.

24 Ibidem.
} 
County, fake cooperative farms were established, which were composed of workers and officials. Farmers were also persecuted during mandatory purchases. According to the Regional Committee:

in a certain period, mass-scale searches in the whole village and among all farmers (regardless of the area of land they owned) were a generally used method in the fight for achieving the target amount of cereal purchases. This method of purchasing cereal was used by most of our party organizations and was the most common form of breaching our Party's line. ${ }^{25}$

Another form involved mandatory threshing. Their number was significant, and in multiple cases they were conducted in order to "completely destroy the kulak, completely crash him". Baranowski mentioned an incident in Szamotuły County, where the owner of a 17-ha holding was forced to kneel in the Presidium of the Community National Council, which was meant to force him to give away his cereals. As he emphasized, "this alleged kulak had a family of 8 adults and all of them worked on the farm. [...] he never hired any labor". In Turek County, party activists dressed a farmer in a sheepskin coat turned inside out, put a label on his neck saying he was the enemy of the people, and marched him around the church when people were leaving it after the mass. Persecuting farmers by writing insults on their fences seems like an innocent game in this context. Very often, their property was illegally auctioned and the party activists who performed the auction purchased the property themselves. In Krotoszyn County, the local First Secretary:

de-kulaked a farmer by taking away his holding and incorporating it into the cooperative farm. He also took away his seeds and fertilizers. He also ordered resistant farmers who did not want to join the cooperative to be arrested.

The authorities' sense of impunity is best evidenced by the fact that the vice-chief of the county Citizens' Militia ordered the arrest of a tailor who put metal stars on his uniform instead of embroidered ones, as mentioned by Baranowski. In Gniezno County, after the cereal purchase operation had finished, "de-kulaking" started in the village, and in Kiszkowo Commune, 9 holdings fell victim to $\mathrm{it}^{26}$.

25 Ibidem.

${ }^{26}$ Ibidem, a statement of Kamermann, the First Secretary of the County Committee in Gniezno. 
There were many more examples of the abuse of power. Baranowski said these were not even abuses of power anymore, but acts of savagery, which crept into the party apparatus.

One might pose a question why incidents like this reoccurred regularly, despite reviews and stigmatization of the culprits. During the abovementioned plenary session, Baranowski said that he thought the reason was the feeble reaction of the Party authorities to such incidents.

After the detection of Party line breaches in Jarocin, the Regional Committee Executive Body did not take this matter seriously enough. We did not understand the danger of this aberration, we did not see clearly enough the political damage that had been done, we did not see the wall that was constructed with these methods between farmers and our Party, the People's power, we did not see the harm done to farmers and to our Party. [...] Therefore the first resolution of the Executive Body was too liberal and did not put halt to such incidents. Only the letters of comrade Bierut and comrade Zambrowski demonstrated the threat presented by the misconduct that had taken place in Jarocin County. We saw the catastrophic results of this liberality soon, as similar breaches of the Party line were revealed in other counties ${ }^{27}$.

The view of the political causes of using illegal methods when establishing cooperative farms, in particular in relation to the so-called medium farmers, was deeply rooted in Stalinism. Baranowski thought this was caused by:

the remnants of the luxemburgism ${ }^{28}$ and social democratic ideologies" as neither movement valued farmers as the allies of the working class or saw revolutionary potential in them. [...] "Therefore, a number of our activists despised farmers as a whole and were very impatient when working in the countryside" 29 .

But the First Secretary also saw the real causes of the problem. He said that:

when organizing cooperative farms, we paid too much attention to figures in the work of the County Committees, and too little to the quality of the newly established cooperatives [...]. We did not perform a thorough analysis regarding the methods by which the cooperatives were established. The chase after the figures and lack of in-depth analysis of the whole situation in every cooperative farm opened up possibilities for breaching the rule of voluntariness ${ }^{30}$.

\footnotetext{
${ }^{27}$ Ibidem.

28 From ideology of Rosa Luxemburg.

${ }^{29}$ Ibidem.

${ }^{30}$ Ibidem.
} 
This led to political rowdiness, which then turned into political degeneration. The "chase after the figures" phrase often echoed in the discussion over the speech. The First Secretary of the County Committee from Jarocin mentioned it, emphasizing that:

comrades wanted to look good in front of their superiors and maybe that is why they bent the rules and forced farmers to establish cooperatives ${ }^{31}$.

Another participant of the discussion commented in a similar fashion:

we fought to have as many cooperatives as possible, we were afraid that some other region would be better, but we did not fight enough for quality. [...] we took external tinsel as reality and often did not see that it concealed internal weakness ${ }^{32}$.

Baranowski also noticed another source of abuse - lack of connection between the Regional Committee and the field, and lack of control over the implementation of resolutions. Finally, he humbly admitted what the essence of the problem was - that the Regional Committee management "was blinded with some, even quite significant, organizational and economic achievements" 33 . Therefore, they turned a blind eye to abuse and tolerated perversion. The system also fostered the creation of local cliques. The word was not used officially, but Baranowski provided an example of such a situation in the County Committee in Krotoszyn, where the local First Secretary committed a number of abuses, breaching fundamental principles of the rule of law and party ethics. It was possible because he controlled the president of the County National Council and the local chief of the Citizens' Militia. This created an atmosphere of terror, in which it was easier to commit and tolerate abuse. For instance, during the 1950 currency reform, the First Secretary tried to evict workers' families from a villa where he wanted to live himself. He also hunted during the protection period and held drinking bouts. Citizens' Militia officers went to the countryside and told farmers in the cooperative to organize a party, during which the officers drank vodka and forced the farmers to serve them.

During the discussion, many interesting analyses of the causes were offered. It was pointed out that many issues were connected with the guide-

\footnotetext{
${ }^{31}$ Ibidem, a statement of Korygacz, the First Secretary of the County Committee in Jarocin.

${ }^{32}$ Ibidem, a statement of Gutman, a PUWP Regional Committee secretary.

${ }^{33}$ Ibidem.
} 
lines and orders received from the central authorities - for instance when Alster, a Central Committee delegate, lectured local authorities not to criticize the purchase plans, but instead to increase efforts to obtain as much cereal as possible. Targets imposed in a top-down manner were impossible to achieve in a normal way ${ }^{34}$. A similar case was described by a secretary of the County Committee from Szamotuly. When the secretary of the Municipal National Council Presidium told Zawadzki (a purchasing representative of the Central Committee) that difficulties with purchasing were caused by excessively ambitious plans and difficult weather conditions, Alster and Zawadzki ordered to have him dismissed. Interestingly, in this case the Municipal Committee did not follow this order, saying that the secretary performed his job well ${ }^{35}$. There were also more orthodox voices. Hetmańska protested against statements that the purchase plan was unrealistic, because during a search in the county, 800 quintals of cereals were discovered. Hetmańska pointed out that the regional party organization did not draw conclusions from the first signals of irregularities when establishing cooperative farms.

One of the reasons of our errors is liberality towards those who breach the party line. If we had punished the perpetrators of the first cases of misconduct [...] and made them an example for the whole party organization, we would have saved many good comrades and, more importantly, there would not have been so much harm done to the Party ${ }^{36}$.

An interesting angle was taken by the Municipal Committee secretary from Ostrów. He said that

both the plans and reports from the purchase operation were flawed, as the committees presented unrealistic reports and provided falsified figures, inconsistent with the reality in the field. In general, this cereal operation was a manifestation of a disrespectful attitude towards the alliance between farmers and workers. The farmers were not asked for their opinion, and plans were made spontaneously, without any reasonable calculations. Here, a reckless attitude of the party committees must be emphasized, as they approached the whole issue in a wrong way ${ }^{37}$.

The same applied to the target number of the cooperative farms established. When the Regional Committee planned these numbers for specif-

${ }^{34}$ Ibidem, a statement of Kaczmarek, a manager of the PUWP Regional Committee Women's Department.

${ }^{35}$ Ibidem, a statement of Mądrachowski, the County Committee secretary from Szamotuły.

${ }^{36}$ Ibidem.

${ }^{37}$ Ibidem, a statement of Kowalski, a Municipal Committee secretary from Ostrów. 
ic county committees in October 1950, no one made any objections or said these were unrealistic ${ }^{38}$. Hetmańska did not think about why the secretaries of the County Committees behaved this way. Migon, the president of the Regional National Council in Poznań, continued the story of passive, indifferent acceptance of the orders "from the top" and said:

a tendency to hide one's head in the sand and to casually ignore breaches of the law originates from the rotten bourgeois principle not to make any enemies. Not to harm anyone, so that no one can harm me. This policy of bourgeois liberality, alien to us, was not combated fiercely enough, we did not struggle to burn in to the ground ${ }^{39}$.

This theme also appeared in the summary of the session made by the Central Committee representative, Nowak. He said that "in the debate, there was little critique towards the Regional Committee", as in his opinion, "the counties are educated so as not to criticize the Regional Committee [...] Criticizing party employees that are superior to us is not very popular". He also added that critique is not about "digging into all nasty business, which can be found in every county". Furthermore, he added in the old spirit that "he wants to antagonize those gathered here against the class enemy, the existence of which some activists seem to have forgotten". He also added that "one of the lessons that must be learned from the Gryfice case is the need for vigilance and mobilizing the whole party apparatus to fight with the class enemy. If the Gryfice case had been an isolated one, it would have been solved quietly, and then only a copy of the resolution would have been sent to the Regional Committee. But these were the acts of barbarian behavior towards people, they violated the rule of law and that is why we had to shake the Party and point it in the right direction. [...] that is why we had to publish this resolution and make a fuss about those events". However, he described a peculiar case of how the class enemy operated, telling a story of a secretary in Września, warned that his predecessors had developed a drinking problem. After two weeks, he also got drunk and walked around the town bare-footed and without his jacket. "We must realize that the class enemy is to blame for that" 40 .

In the discussion one more theme appeared. County secretaries pointed out the harmfulness of the Central Committee resolution on the Gryfice case, emphasizing that this was understood by some farmers as an omen

38 Ibidem, a statement of Wiktoria Hetmańska.

${ }^{39}$ Ibidem, a statement of Migon, the president of the Regional National Council in Poznań.

${ }^{40}$ Ibidem, a statement of Z. Nowak, a PUWP Central Committee secretary. 
of fundamental transformations in the agricultural policy. One teacher in Oborniki County said that:

the days of party secretaries and Security Office heads are over. There are even cases where kulaks antagonize farmers against cooperatives, they even gather to discuss in detail how to spread hostile propaganda and hostile actions towards the Central Committee resolution ${ }^{41}$.

A similar problem was mentioned during county meetings. In Chodzież County, there were voices saying that: "the class enemy is trying to use the resolution of the Central Committee on Gryfice to antagonize farmers who are members of cooperative farms, in order to destroy the established cooperatives. People are being told to leave the cooperatives or to say that the cooperative was established under pressure and threats" 42 . Representatives of a cooperative from Oborniki County spoke in a similar spirit. They said that "kulaks tried to scare us - members of the cooperative farm - that we would have to give them back the cows bought from them during auctions. In Kościan County, cooperative farm members did not want to live in the palace, as they were convinced the previous owner would return" 43 .

After the Regional Committee plenary session, similar meetings took place in the County Committees on July 6 and 7, 1951. According to the Regional Committee, introductory speeches were prepared adequately. They provided further examples of breaking the rule of law, primarily during the cereal purchase operations. In Koło County for instance, a party activist ordered all cereal to be taken away from a farmer who was behind on his deliveries. He did not want to hear arguments that the farmer had a large family and would not have enough food to feed them. However, the participants of the meeting were not eager to take the floor, especially to make complaints. Very often they had to be forced to voice their opinion. It was generally accepted that "it is better not to talk about these things (that is, acts of abuse), as you can be detained for them". Most frequently, they criticized Gryfice, but they did not elaborate to discuss their own territory. Therefore, for instance, in Gniezno:

\footnotetext{
${ }^{41}$ Ibidem, statement of Strachanowski, the Second Secretary of the County Committee in Oborniki.

42 National Archive in Poznań, sign. 271. Report evaluating the course of plenary meetings of the County and Municipal Committees on July 6 and 7, 1951.

${ }^{43}$ Ibidem.
} 
the discussion resembled a 'communal work': you were obliged to say something, anything, even on an unrelated subject ${ }^{44}$.

Publicizing the abuses during the collectivization of the countryside throughout the country was meant to be the evidence that, even though the Party inadvertently allowed that to happen, it learned its lesson, and from now on, the establishment of socialism in the countryside would take place according to the right rules. This turned out to be far from the truth. The ritual shows of criticism only concerned selected cases, and their main aim was to "take arguments away from the political enemies" and show that the Party can admit to making mistakes and purge itself. The campaign of 1951 did not lead to eliminating the actual causes of misconduct in this area. The goal remained the same - soon the whole Polish countryside was to enter the path of socialist economy. To a large extent, the mechanism that was meant to take it there did not change as well. The central authorities demanded significant activity in this area from their field operators. The field operators reacted according to the well-known formula, and returned to old, tried and tested methods. This is best evidenced by the fact that in subsequent years, debates on the irregularities in the process of collectivization of the countryside were held on a regular basis. During a plenary session of the Regional Committee in August 1952, the First Secretary made a speech on "shortcomings and mistakes made by the regional party organization in the fight for the development of cooperative farms, and on some most urgent tasks for the Party in the countryside" 45 . To a large extent, the speech contained the same old theses, and the result was also the same. When a year later there was not enough cereal, the Central Committee agents were ordered to arrest farmers and make the cereals "flow" again. Shortages of cereals were traditionally considered to be a result of the "kulaks' plot", and the only solution was seen in a shower of fines imposed on kulaks ${ }^{46}$.

${ }^{44}$ Ibidem.

${ }^{45}$ National Archive in Poznań, PUWP Regional Committee, sign. 53, minutes of the PUWP Regional Committee plenary session in Poznań, August 2, 1952.

46 National Archive in Poznań, sign. 963/II 250, shorthand report of the minutes from the meeting of the presidents of the County National Council Presidium, Ruling Councils, chief of the Citizens Militia, Security Office etc., November 2, 1952, see: Jankowiak S., (1995) Wielkopolska w czasie stalinizmu [Greater Poland in a time of Stalinism], Poznań, p. 94. 


\section{CONCLUSIONS}

Systematic stigmatization of illegal methods used during the establishment of cooperative farms is the evidence that the principles themselves were flawed. Accountability of the activists for the results, combined with leniency towards abuses of power and forcing farmers to join by threats and repressions, meant that the cost of the operation was enormous. More importantly, these actions took away any hope for normality, which in combination with the massive burden imposed on the countryside in the form of mandatory deliveries only discouraged farmers from working. As a result, agricultural production fell drastically, as demonstrated by massive food shortages occurring as early as 1953. Furthermore, the system could not be changed, and most cooperatives established using illegal methods fell apart after 1956. The fact that those guilty of abuses in the implementation of the Party's policy in the countryside never faced any serious consequences remains a separate problem.

\section{BIBLIOGRAPH}

Ideological declaration of the PUWP, “Nowe Drogi” [New ways], 1949, no. 1.

Jankowiak S. (1995), Wielkopolska w okresie socjalizmu 1948-1956 [Greater Poland in the period of socialism 1948-1956], Poznań.

National Archive in Poznań, Domestic Affairs Office, sign. 77, Situational report for the $2^{\text {nd }}$ quarter of 1950.

National Archive in Poznań, PUWP Regional Committee, sign. 263, Minutes no. 52 from the session of the PUWP Regional Committee Executive Body on December 20, 1950.

National Archive in Poznań, PUWP Regional Committee, sign. 264, Minutes of the meeting of the PUWP Regional Committee Executive Body on January 31, 1951.

National Archive in Poznań, PUWP Regional Committee, sign. 46, minutes of the PUWP Regional Committee plenary session of January 11, 1951.

National Archive in Poznań, PUWP Regional Committee, sign. 48, Minutes of the plenary session of PUWP Regional Committee of June 13, 1951.

National Archive in Poznań, PUWP Regional Committee, sign. 53, minutes of the PUWP Regional Committee plenary session in Poznań, August 2, 1952.

National Archive in Poznań, sign. 263, the Resolution of the PUWP Regional Committee Executive Body of December 20, 1950.

National Archive in Poznań, sign. 265, a letter of PUWP Regional Committee in Poznań to B. Bierut, the president of the PUWP Central Committee in Warsaw of February 14, 1951.

National Archive in Poznań, sign. 271. Report evaluating the course of plenary meetings of the County and Municipal Committees on July 6 and 7, 1951. 
National Archive in Poznań, sign. 963/II 250, shorthand report of the minutes from the meeting of the presidents of the County National Council Presidium, Ruling Councils, chief of the Citizens Militia, Security Office etc., November 2, 1952.

O budownictwie partyjnym. Uchwaty Komitetu Centralnego Polskiej Zjednoczonej Partii Robotniczej 1949-1953 [On the Party construction industry. Resolutions of the Polish United Worker's Party Central Committee 1949-1953], Warsaw, 1954.

Shorthand report of the plenary session of the PUWP Central Committee, April 13-14, 1947 [in] Archiwum Ruchu Robotniczego [Archive of the Workers' Movement], vol. 7, Warsaw, 1982.

The Archive of New Files in Warsaw, PUWP Central Committee, sign. 237/VII-1792, Report of the PUWP Regional Committee in Poznan for the period from March 15 to April 15, 1949.

Stanisław Jankowiak - Professor, head of the Modern Polish History Deparment of the Adam Mickiewicz University Institute of History. His research concerns Poland's modern history, particularly political history (fight for power in Poland after the Second World War, the Poznań June, Stalinism, student strikes, the Solidarity movement, systemic transformation after 1989, secret services operation in the Polish People's Republic), issues of national identity (especially the situation of Germans after the Second World War) and relationships between the church and the state. 